\title{
PERIURETHRAL COLLAGEN FOR URINARY INCONTINENCE AFTER GENDER REASSIGNMENT SURGERY
}

\author{
CHRISTOPHER FITZPATRICK, M.D. F.R.C.S. (EDIN) \\ STANLEY J. SWIERZEWSKI, III, M.D. \\ EDWARD J. MCGUIRE, M.D.
}

From the Department of Surgery, Section of Urology, University of Michigan
Medical Center, Ann Arbor, Michigan

\begin{abstract}
We report on 2 patients, one female and one male transsexual; in both, Type III stress urinary incontinence developed after gender reassignment surgery. Both patients were treated by periurethral injection of gluteraldehyde cross-linked collagen resulting in a marked symptomatic improvement in association with a significant rise in abdominal leak point pressures. We believe these are the first reported cases of collagen injection being used for urinary incontinence after gender reassignment surgery.
\end{abstract}

The reported prevalence of transsexualism varies between $1: 25,000$ and $1: 100,000$ with a reported male:female ratio of between $5: 1$ and 20:1. ${ }^{1-3}$ Considerable controversy exists regarding the indications for gender reassignment surgery as well as the various surgical techniques used. For patients undergoing this type of surgery, specific postoperative complications include graft infection, fistula formation, urethral and neovaginal stenosis, impotence, and continuing psychosexual dysfunction. ${ }^{4-7}$ Although urethral and vesical fistulas appear to be the most common cause of urinary incontinence, the urethral sphincteric mechanism also may be disrupted as a result of surgery.

Twenty years ago, polytef was introduced for the treatment of stress urinary incontinence. ${ }^{8,9}$ Subsequent long-term follow-up has lead to concern of particle migration and long-term results. ${ }^{10-12}$ Periurethral collagen has been used successfully for the treatment of patients with intrinsic sphincter dysfunction without associated morbity. ${ }^{13}$

Collagen, a glutaraldehyde cross-linked bovinederived material has been the subject of a multicenter study. ${ }^{14-18}$ Briefly, the material produces a significant increase in the ability of the urethra to withstand abdominal pressure as an expulsive force. ${ }^{19,20}$ In a three-year follow-up period, 80 percent of patients who became continent after colla-

Submitted: February 12, 1993, accepted (with revisions): June 24, 1993 gen injection remained continent. ${ }^{17}$ The primary indication for use of the material is poor intrinsic urethral closing function associated with leakage at low to very low abdominal pressures. ${ }^{21-23}$ In females, this type of incontinence is associated with a fixed urethral position and leakage at abdominal pressures less than $60 \mathrm{~cm}$ of water. ${ }^{20}$ In males, incontinence after prostatectomy leakage occurs at abdominal pressures less than $100 \mathrm{~cm}$ of water. ${ }^{18}$

We report on 2 transsexual patients, one female and one male; in both severe stress incontinence developed after gender reassignment surgery. Both patients were treated by periurethral injection of gluteraldehyde cross-linked collagen resulting in marked symptomatic improvement in association with a significant rise in abdominal leak point pressures. We believe these are the first reported cases of collagen injection being used for urinary incontinence after gender reassignment surgery.

\section{CASE REPORTS}

CASE 1

A thirty-five-year-old female transsexual with severe stress urinary incontinence was referred to the University of Michigan Medical Center. The patient had undergone gender reassignment surgery over three years previously. This included a colpohysterectomy, adnexectomy, bilateral mastectomy, phalloplasty (using a rectus abdominis muscle graft), and urethra transposition. $\mathrm{Nu}$ merous postoperative complications developed 


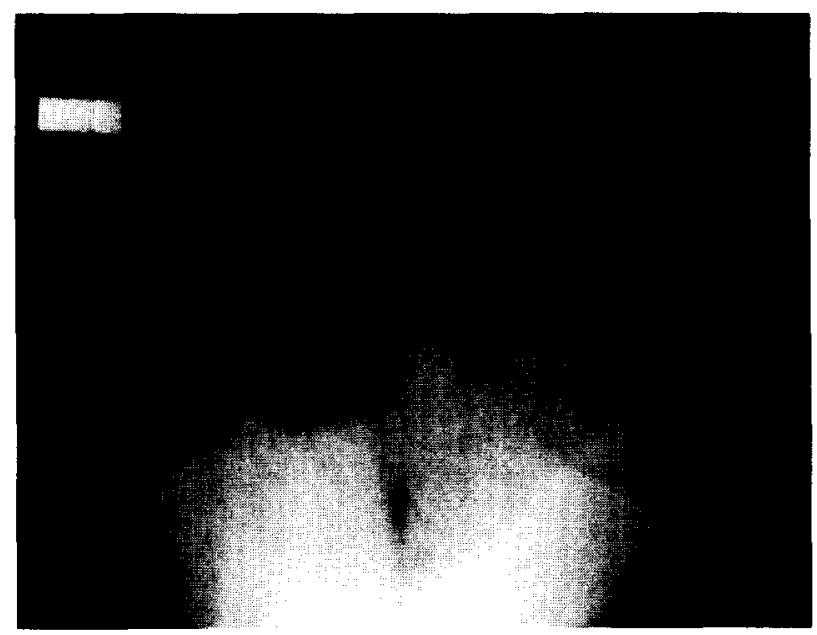

FIGURE 1. Abdominal leak point pressure of $28 \mathrm{~cm}$ water in female transsexual after gender reassignment surgery.

including recurrent urethrocutaneous fistulas, urethral diverticula, urethral calculi, meatal stenosis, and severe stress urinary incontinence. Further reconstructive procedures were performed including a gracilis myocutaneous graft to the site of recurrent fistula formation, perineal urethroplasty, and bladder neck needle suspension. The patient remained incontinent, voiding urine through the site of the original urethral meatus. Fluorourodynamic evaluation revealed severe Type III stress urinary incontinence with a widely open bladder neck and an abdominal leak point pressure of 28 $\mathrm{cm}$ water (Fig. 1). Over the following eighteen months, this patient underwent cystoscopic transurethral collagen injection on four occasions. A total of $70 \mathrm{cc}$ of collagen was used. Ten months after the last treatment, her leak point pressure is in excess of $128 \mathrm{~cm}$ water. She enjoys a significant symptomatic improvement, only wearing a pad during jogging for minimal stress urinary incontinence.

\section{CASE 2}

A thirty-seven-year-old male transsexual presented with stress urinary incontinence, having undergone gender reassignment surgery more than three years previously. This included bilateral breast augmentation, bilateral orchiectomy, penectomy, urethral transposition, and vaginoplasty using invaginated penoscrotal flaps. Postoperative complications included graft infection, vaginal stenosis, and urinary incontinence. The patient was maintained on continuous oral estrogen. Fluorourodynamic evaluation revealed Type III stress urinary incontinence with a leak point pressure of $87 \mathrm{~cm}$ water (Fig. 2). Digital rectal examination

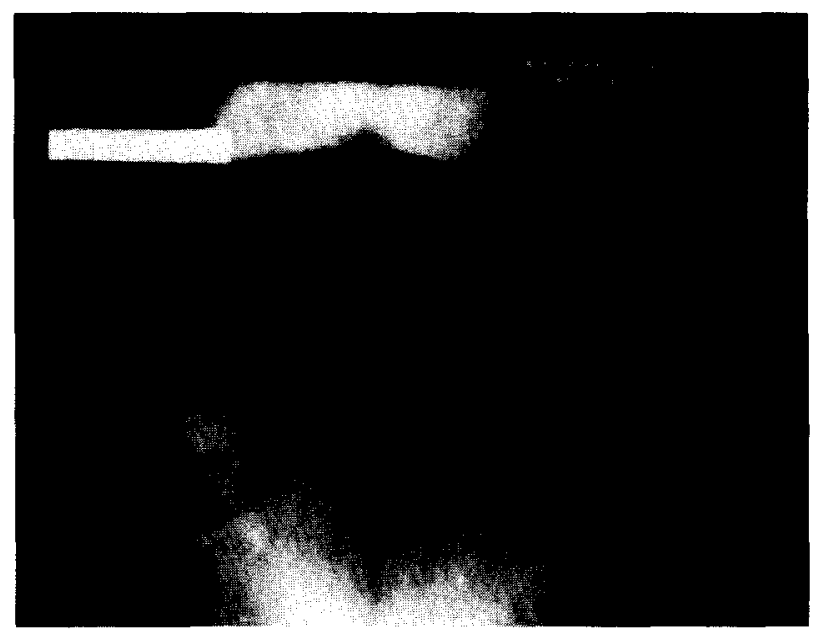

FIGURE 2. Abdominal leak point pressure of $87 \mathrm{~cm}$ water in male transsexual after gender reassignment surgery.

revealed an atrophic prostate gland. This patient subsequently underwent cystoscopic transurethral collagen injection on two occasions. A total of 25 cc of collagen were used. Seven months after the last treatment, this patient complains only of mild urge urinary incontinence. Repeat fluorourodynamic assessment reveals a leak point pressure of $126 \mathrm{~cm}$ water.

\section{COMMENT}

Direct urethral sphincter injury and denervation are the probable causes of Type III stress urinary incontinence in both patients reported. In the male transsexual patient, estrogen-induced prostate atrophy may be an additional factor contributing to incontinence. Surgical correction of Type III stress urinary incontinence requires either sling suspension of the bladder neck or artificial sphincter insertion. ${ }^{24.25}$ Anatomic distortion and tissue fibrosis in these cases would render these procedures both technically difficult and potentially hazardous.

Injectable collagen has been available since 1983 and was initially used in plastic surgery. ${ }^{26}$ Studies revealed that the majority of collagen was reabsorbed in ninety days. ${ }^{27}$ Since that time, collagen has been cross-linked with gluteraldehyde which in human studies seems to provide a matrix for the ingrowth of host collagen providing a more permanent urethral coaptation. ${ }^{18,28}$

The results of multicenter trials suggest that glutaraldehyde cross-linked collagen maintains a urethral continence effect against abdominal pressure for periods up to two years after injection. ${ }^{17,18,20,21}$ The effect is objectively measured by 
determining the amount of abdominal pressure required to induce urinary leakage prior to and following collagen injection. That measurement is the most valid method to assess the strength of the urethral sphincter vis a vis abdominal pressure. Collagen injection provided a significantly lower risk therapeutic option for the patients described in this report. Both tolerated the procedure well and were satisfied with the outcome. Although the indications and techniques of gender reassignment surgery remain subjects of controversy, periurethral collagen injection appears to have a role in the treatment of urinary incontinence arising after such surgery.

$$
\begin{array}{r}
\text { Stanley J. Swierzewski, III, M.D. } \\
\text { Catherine Horan Medical Building } \\
1221 \text { Main Street } \\
\text { Holyoke, Massachusetts } 01040
\end{array}
$$

\section{REFERENCES}

1. Pauly IB: The current status of the change of sex operation. J Nerv Ment Dis 147: 460-471, 1968.

2. Tsoi WF, Kok LP, and Long FY: Male transsexualism in Singapore: a description of 56 cases. $\mathrm{Br} J$ Psychiat 131: 405-409, 1977.

3. Rattram SS, and Lim SM: Surgical treatment of transsexualism, in Studd J (Ed): Progress in Obstetrics and Gynecology, Edinburgh, Churchill \& Livingstone, vol 2, chap 33, 1982, p 264.

4. Lim M: Surgery in transsexuals. Ann Acad Med Singapore 15: 122-126, 1986

5. Small MP: Penile and scrotal inversion vaginoplasty for male to female transsexuals. Urology 29: 593-597, 1987.

6. Ratnam SS, and llancheran A: Sex reassignment in the male transsexual. Br J Hosp Med 38: 204-208, 212-213, 1987.

7. Ross MW, and Need JA: Effects of adequacy of gender reassignment surgery on psychological adjustment: a followup of fourteen male-to-female patients. Arch Sex Behav 18: 145-153, 1989.

8. Berg S: Polytef augmentation urethroplasty. Correction of surgically incurable urinary incontinence by injection technique. Arch Surg 107: 379-381, 1973.

9. Politano VA, Small MP, Harper JM, and Lynne CM: Periurethral Teflon injection for urinary incontinence. J Urol 111: 180-183, 1974.

10. Malizia AA Jr, Reiman HM, Myers RP, Sande JR, Barham SS, Benson RC Jr, Dewanjee MK, and Utz WS: Migration and granulomatous reaction after periurethral injection of Polytef (Teflon). JAMA 251: 3277-3281, 1984.

11. Claes H, Stoobants D, Van Meerbeek J, Verbeken E, Knockaert D, and Baert L: Pulmonary migration following periurethral polytetrafluoroethylene injection for urinary in- continence. J Urol 142: 821-822, 1989.

12. Beckingham IJ, Wemyss-Holden $G$, and Lawrence WT: Long-term follow-up of women treated with periurethral Teflon injections for stress incontinence. Br J Urol 69: $580-583,1992$.

13. Shortliffe LM, Freiha FS, Kessler R, Stamey TA, and Constantinou CE: Treatment of urinary incontinence by the periurethral implantation of gluteraldehyde cross-linked collagen. J Urol 141: 538-541, 1989.

14. Appel RA, Goodman JR, McGuire EJ, Wang SC, Bennett AH, DeRidder PA, and Webster GD: Multicenter study of peri and transurethral Gax collagen injection for urinary incontinence (Abstr 758). J Urol 141: 359A, 1989.

15. MCGuire EJ, Wang SC, Appell RA, Webster GD, DeRidder PA, and Bennett AH: Treatment of urethral incontinence by collagen injection: one-year follow-up (Abstr 142). J Urol 143: 224A, 1990.

16. Appell RA, McGuire EJ, DeRidder PA, Bennett AH, and Webster GD: Results of the multicenter study using injectable Gax-collagen in females (Abstr 51). J Urol 145: 225A, 1991.

17. Appell RA, McGuire EJ, DeRidder PA, Bennett AH, and Webster GD: Updated multicenter study on the use of Gax collagen for female type III stress urinary incontinence (Abstr 264). J Urol 147: 279A, 1992.

18. Appell RA, McGuire EJ, DeRidder PA, Bennett AH, Webster GD, Bennet JK, and Badlani GH: Updated multicenter study on the use of Gax collagen for male urinary incontinence due to outflow incompetence (Abstr 747). J Urol 147: 399A, 1992.

19. McGuire EJ: Active and passive factors in urethral continence function. Int Urogynecol J 3: 54-60, 1992.

20. McGuire EJ, and Appell RA: Collagen injection for the dysfunctional urethra. Contemp Urol 3: 11-14, 16, 19, 1991

21. Wan J, McGuire EJ, Bloom DA, and Ritchey ML: The treatment of urinary incontinence in children using glutaraldehyde cross-linked collagen. J Urol 148: 127-130, 1992.

22. Bloom DA, and McGuire EJ: Collagen injection therapy in children with myelodysplasia. Dialog Pediatr Urol 14: $2-3,1991$.

23. Ortenberg J, Appell RA, Harmon EP, Bloom DA, and McGuire EJ: Preliminary results of collagen injections for urinary incontinence in children (Abstr 580). J Urol 147: 357A, 1992.

24. McGuire EJ, and Lytton B: Pubovaginal sling procedure for stress incontinence. J Urol 119: 82-84, 1978.

25. Scott FB: The use of the artificial sphincter in the treatment of urinary incontinence in the female patient. Urol Clin North Am 12: 305, 1985.

26. Kaplan EN, Falces E, and Tolleth H: Clinical utilization of injectable collagen. Ann Plast Surg 10: 437-451, 1983.

27. Kligman AM, and Armstrong RC: Histologic response to intradermal Zyderm and Zyplast (glutaraldehyde crosslinked) collagen in humans. J Dermatol Surg Oncol 12: $351-357,1986$. 